\title{
PENGARUH KONDISI FISIK DAN JARAK SUMUR GALI DENGAN PETERNAKAN SAPI TERHADAP KANDUNGAN BAKTERI COLIFORM AIR SUMUR GALI DI DESA SUKAJAYA KECAMATAN LEMBANG KABUPATEN BANDUNG BARAT
}

\author{
Yonik Meilawati Yustiani*, Astri Widiastuti Hasbiah, Rusli Fuad \\ Program Studi Teknik Lingkungan, Universitas Pasundan
}

\begin{abstract}
Abstrak
Sebagian penduduk Desa Sukajaya Kecamatan Lembang Kabupaten Bandung Barat menggunakan sumur gali sebagai sarana sumber air bersih yaitu sumur gali. Lokasi sumur tersebut yang berdekatan dengan sumber pencemaran yaitu peternakan sapi. Tujuan penelitian ini adalah mengidentifikasi poteni pencemaran air sumur akibat kegiatan peternakan sapi tersebut dilihat dari parameter Coliform. Variabel yang diteliti pengaruhnya adalah kondisi fisik sumur dan jarak peternakan sapi terhadap sumur. Penelitian ini bersifat observasional dengan desain cross sectional. Populasi 41 sumur gali dan sampel 24 sumur gali. Hypotesis ada hubungan jarak peternakan sapi dengan keadaan fisik sarana sumur gali (dinding, bibir, lantai dan penutup sumur terhadap kandungan bakteri coliform air sumur gali). Teknik pengambilan sampel yang digunakan adalah purposive sampling pada suatu pertimbangan dengan kriteria inklusi dan ekslusi. Hasil penelitian menunjukan bahwa dari 24 sumur gali diobservasi jarak terhadap sumber pencemar (peternakan sapi) $\geq 15 \mathrm{~m}$ yang tidak memenuhi syarat $100 \%$ dan terhadap parameter keadaan fisik yaitu dinding sumur kedap air $\geq 3$ m tidak memenuhi syarat100 \%, ketinggian bibir sumur $\geq 70-75$ $\mathrm{cm}$ tidak memenuhi syarat $70,83 \%$, lantai sumur gali kedap air radius $\geq 1 \mathrm{~m}$ tidak memenuhi syarat $74,17 \%$ dan penutup sumur gali kedap air yang tidak memenuhi syarat 54,17\% serta kandungan coliform air sumur gali tidak memenuhi syarat $100 \%$ (Standar non perpipaan dan perpipaan 0 MPN/100 ml). Berdasarkan analisis pengukuran dan observasi di lapangan secara signifikan ada hubungan jarak sumur gali dengan peternakan sapi, keadaan fisik dinding sumur gali, keadan fisik bibir sumur gali, keadaan fisik lantai, dan keadaan fisik penutup yang tidak memenuhi syarat dapat menyebabkan kontaminasi bakteri coliform pada air sumur gali.
\end{abstract}

Kata kunci: Coliform, Jarak Sumur-Peternakan Sapi, Kondisi Fisik Sumur

\section{Pendahuluan}

Salah satu jenis sarana penyediaan air bersih pedesaan yang banyak diusahakan oleh pemerintah sebagai sumber air bersih adalah sumur gali. Air tanah lebih banyak penggunaannya karena lebih mudah

${ }^{*}$ Penulis Korespondensi:

E-mail: yonik@unpas.ac.id

Diterima pertama kali: 10 Mei 2017

Direvisi : 1 Agustus 2017

Disetujui untuk publikasi: 17 Agustus 2017 mendapatkannya dan relatif lebih aman dari pencemaran apabila dibandingkan dengan air permukaan. Kualitas air sumur gali dapat tercemar yang disebabkan oleh bermacammacam faktor, diantaranya oleh limbah rumah tangga/industri, sampah, tinja dan oleh karena pembuatan jamban yang kurang baik atau tidak memenuhi kaidah teknis dengan baik, akan terbuka pencemaran yang ditimbulkan oleh bakteri terhadap air yang ada di dalam tanah baik secara lansung maupun tidak langsung melalui vector/ bibit pembawa penyakit. Sumur 
gali yang sudah digunakan dalam waktu relatif lama/barunya akan dapat berpengaruh terhadap pencemaran dilihat dari jarak dan siklus bakteriologis, karena selain bertambahnya sumber pencemar juga lebih mudahnya sumber pencemar merembes ke dalam sumur mengikuti aliran air tanah yang berbentuk memusat ke arah sumur (Chandra, 2006).

Air yang mengandung banyak bakteri golongan Coliform akan kurang baik sebagai sumber air minum. Menurut Permenkes No. 492 tahun 2010 tentang Persyaratan Kualitas Air Minum, batas kehadiran bakteri Coliformdalam air bersih atau air minum adalah 0 MPN/100 ml untuk air minum non perpipaan dan perpipan. Coliform merupakan organisme yang lebih resisten terhadap proses purifikasi air secara alamiah. Bila Coliform ini ditemukan di dalam sampel air maka dapat diambil kesimpulan bahwa kuman usus patogen yang lain dapat juga ditemukan dalam sampel air tersebut di atas walaupun dalam jumlah yang kecil (Chandra, 2006).

Pemeliharaan sapi perah erat hubungannya dengan pemeliharaan lingkungan dan kesehatan. Salah satu sumber pencemaran terhadap lingkungan adalah peternakan sapi perah melalui kotoran yang dikeluarkan setiap hari melalui proses pengeluaran sisa pencernaan atau feses (defekasi). Kotoran sapi dalam jumlah besar dapat menjadi sumber pencemaran. Oleh karenanya harus ditangani secara serius untuk mencegah terjadinya kontaminasi terhadap air, udara, tanah yang berdampak timbulnya gangguan kesehatan manusia. Kotoran hewan merupakan sumber mikroorganisme, karena mengandung substrat yang digunakan mikroorganisme untuk produksi methan. Bakteri dalam kotoran sapi berasal dari bakteri yang hidup dalam usus disebut juga golongan Enterobacter. Beberapa spesies bakteri dalam usus dapat menyebabkan gastroenteritis.

Desa Sukajaya merupakan salah satu sentral peternakan yang ada di wilayah kecamatan lembang Kabupaten Bandung Barat. Sebagian besar penduduk di sana berprofesi sebagai peternak sapi yang dikelola oleh pihak koperasi/swasta. Berdasarkan observasi di lapangan adanya jarak sumur gali dengan peternakan sapi di Desa Sukajaya Kecamatan Lembang Kabupaten Bandung Barat tahun 2016 diketahui bahwa sumur gali di Desa Sukajaya Kecamatan Lembang Kabupaten Bandung Barat banyak yang sudah tercemar oleh limpasan yang mengandung kotoran sapi akibat jarak sumur gali dengan peternakan sapi tidak memenuhi syarat.

Tujuan dari penelitian ini adalah mengidentifikasi pengaruh kondisi fisik dan jarak sumur gali dengan peternakan sapi terhadap kandungan bakteri Coliform dalam ari sumur gali di Desa Sukajaya Kecamatan Lembang, Kabupaten Bandung Barat.

\section{Metodologi Kajian}

\section{Rancangan Sampel}

Populasi adalah keseluruhan objek penelitian atau objek yang diteliti. Sampel adalah sebagian dari keseluruhan objek yang diteliti dan dianggap mewakili seluruh populasi (Notoatmodjo, 2010).

Populasi dalam penelitian ini adalahkeseluruhan sumur gali yang masih dimanfaatkan warga di sekitar peternakan sapi di desa sukajaya yaitu 41 sumur. Sedangkan sampel dalam penelitian ini adalah sebagian dari sumur gali sesuai kriteria yang diambil di sekitar peternakan sapi, desa sukajayayaitu 24 sumur.

Besaran sampel pada penelitian ini adalah sebanyak 24 sampel sumur gali. Merupakan jumlah sarana sumber air bersih yang berasal dari sumur gali di Desa Sukajaya Kecamatan Lembang Kabupaten Bandung Barat. Maka besaran sampel dapat dilihat pada Tabel 1 . 
Tabel 1. Jumlah Sampel Sarana Air Bersih Sumur Gali Di Desa Sukajaya Kecamatan Lembang Tahun 2015

\begin{tabular}{ccc}
\hline Wilayah & $\begin{array}{c}\text { Jumlah } \\
\text { (unit) }\end{array}$ & $\begin{array}{c}\text { Persentase } \\
(\%)\end{array}$ \\
\hline RW 01 & 4 & 16,6 \\
RW 02 & 3 & 12.5 \\
RW 04 & 3 & 12,5 \\
RW 05 & 4 & 16,6 \\
RW 06 & 4 & 16.6 \\
RW 13 & 3 & 12,5 \\
RW 14 & 3 & 12,5 \\
\hline Jumlah & 24 & 99,8 \\
\hline
\end{tabular}

\section{Rancangan Sampel}

Teknik pengambilan sampel sumur gali yang digunakan adalah Non Random Sampling yaitu Purposive Sampling, pengambilan sampel secara Teknik Pengambilan Sampel Purposive didasarkan pada suatu pertimbangan sesuai dengan kriteria inklusi dan ekslusi yang dibuat oleh peneliti sendiri, berdasarkan ciri atau sifatsifat populasi yang sudah diketahui sebelumnya, sampel pun diarahkan kepada karakteristik yang spesifik (Notoatmodjo, 2010).

Besaran sampel pada penelitian ini adalah sebanyak 24 sampel sumur gali. Agar karakteristik sampel tidak menyimpang dari populasinya, maka sebelum dilakukan pengambilan sampel ditentukan kriteria inklusi atau ciri ciri yang perlu dipenuhi setiap anggota populasi yang dapat diambil sampel, maupun kriteria eksklusi atau ciri-ciri anggota populasi yang tidak dapat diambil sebagai sampel (Notoatmodjo, 2010).

Untuk menentukan jumlah sampel yang diambil dalam penelitian ini dari keseluruhan sampel yaitu 41 sampel sumur gali yang aktif digunakan, diambil sekitar $50 \%$ atau setengah dari jumlah keseluruhan sampel maka diperoleh sampel dalam penelitian ini sebanyak 24 sampel sumur gali yang disesuaikan dengan kriteria atau ciri-ciri sampel yang sudah ditentukan sebagai berikut :
1. Kriteria inklusi

a. Sumur berada di sekitar peternakan sapi.

b. Sumur harus berjarak minimal 10 meter dari sumber pencemar seperti septictank, cubluk dan tempat sampah.

c. Masih aktif digunakan untuk keperluan sehari hari.

2. Kriteria eksklusi

a. Tidak berada di sekitar peternakan sapi.

b. Sumur tidak berjarak minimal 10 meter dari sumber pencemar seperti septictank, cubluk dan tempat sampah.

c. Sudah tidak aktif untuk digunakan untuk keperluan sehari hari.

Teknik pengambilan sampel air secara bakteriologis yang digunakan adalah dengan teknik pengambilan sampel air sesaat (grab sample), yaitu sampel yang diambil secara langsung dari badan air yang sedang dipantau. Sampel ini hanya menggambarkan karakteristik air pada saat pengambilan sampel. Sampel air diambil sesuai dengan prosedur pengambilan sampel air untuk pemeriksaan bakteriologis yaitu dengan prinsip menghindari terjadinya kontaminasi. Untuk mencapai kondisi tersebut semua wadah dan peralatan dalam kondisi steril.

\section{Hasil dan Pembahasan}

\section{Hubungan Jarak Sumur Gali Dengan Bakteri Coliform}

Setelah sampel air diperiksa kandungan coliform dan pengukuran keadaan fisik selanjutnya di buat tabel hubungan jarak sumur gali dengan bakteri coliform dengan membandingkan standar "Memenuhi Syarat (MS)" dan "Tidak Memenuhi Syarat (TMS)". 
Tabel 2. Hubungan Jarak Sumur Gali Terhadap

Coliform Di Desa Sukajaya Kecamatan Lembang

\begin{tabular}{|c|c|c|c|c|}
\hline Sampel & $\begin{array}{c}\text { Jarak } \\
\text { Sumur } \\
\text { (Meter) }\end{array}$ & $\begin{array}{c}\text { Standart } \\
\text { Jarak (>15 } \\
\text { Meter) }\end{array}$ & $\begin{array}{c}\text { Coliform } \\
\text { MPN/100 } \\
\text { ml }\end{array}$ & $\begin{array}{c}\text { Standart } \\
\text { Coliform } \\
(50 \mathrm{MPN} / \\
\mathbf{1 0 0 \mathrm { ml } )}\end{array}$ \\
\hline 1 & 10.5 & TMS & 120 & TMS \\
\hline 2 & 1.6 & TMS & 460 & TMS \\
\hline 3 & 1.9 & TMS & 1100 & TMS \\
\hline 4 & 3.2 & TMS & $2400+$ & TMS \\
\hline 5 & 5.1 & TMS & 290 & TMS \\
\hline 6 & 1.8 & TMS & $2400+$ & TMS \\
\hline 7 & 7.6 & TMS & 210 & TMS \\
\hline 8 & 1 & TMS & 1100 & TMS \\
\hline 9 & 2.1 & TMS & 460 & TMS \\
\hline 10 & 2 & TMS & 150 & TMS \\
\hline 11 & 2.7 & TMS & $2400+$ & TMS \\
\hline 12 & 6.3 & TMS & 290 & TMS \\
\hline 13 & 2.2 & TMS & $2400+$ & TMS \\
\hline 14 & 3.1 & TMS & $2400+$ & TMS \\
\hline 15 & 4.3 & TMS & $2400+$ & TMS \\
\hline 16 & 2.4 & TMS & $2400+$ & TMS \\
\hline 17 & 2.1 & TMS & $2400+$ & TMS \\
\hline 18 & 4.2 & TMS & $2400+$ & TMS \\
\hline 19 & 3.6 & TMS & $2400+$ & TMS \\
\hline 20 & 3.4 & TMS & $2400+$ & TMS \\
\hline 21 & 1.2 & TMS & $2400+$ & TMS \\
\hline 22 & 2.1 & TMS & 75 & TMS \\
\hline 23 & 1 & TMS & 1100 & TMS \\
\hline 24 & 1 & TMS & $2400+$ & TMS \\
\hline
\end{tabular}

Dari Tabel 2 di atas maka jarak sumur gali terhadap peternakan sapi di Desa Sukajaya Kecamatan Lembang Kabupaten Bandung Barat cenderung "Tidak Memenuhi Syarat" dari kandungan bakteri Coliform.

Dari hasil observasi dan pengukuran, sebanyak 24 buah sumur gali dikategorikan tidak memenuhi syarat $100 \%$ dari segi jarak dengan sumber pencemar> 15 meter (peternakan sapi). pada kenyataan di lapangan masih banyak ditemukan jarak sumur gali yang < 15 meter dari sumber pencemar (peternakan sapi), hal ini disebabkan banyak rumah warga yang memiliki lahan dan halaman yang berubah fungsi menjadi kandang ternak sapi sederhana karena usaha peternakan disana cukup menjanjikan untuk penghasilan tambahan bagi warga sekitar. Sementara untuk saluran pembuangan air limbah (SPAL) kandang ternak disana langsung dialirkan ke permukaan tanah dengan lokasi peternakan lebih tinggi dari sarana sumur gali. Hal ini yang menjadi penyebab masalah kandungan bakteriologis Coliform air sumur gali disana tidak memenuhi syarat.

Dalam teori disebutkan dari sudut pandang sanitasi, yang penting diperhatikan adalah jarak perpindahan maksimum dari bahan pencemar dan kenyataan bahwa arah perpindahan selalu searah dengan arah aliran air tanah. Dalam penempatan sumur, harus diingat bahwa air yang berada dalam lingkaran pengaruh sumur mengalir menuju sumur tersebut. Tidak boleh ada bagian daerah kontaminasi kimiawi ataupun bakteriologis yang berada dalam jarak jangkau lingkaran pengaruh sumur.

Penentuan persyaratan dari sumur gali didasarkan pada hal-hal sebagai berikut: Kemampuan hidup bakteri patogen selama 3 hari dan perjalanan air dalam tanah 3 meter/hari atau lebih. Kemampuan bakteri patogen menembus tanah secara vertical sedalam 3 meter. Kemampuan bakteri patogen menembus tanah secara horizontal sejauh 1 meter. Kemungkinan terjadinya kontaminasi pada saat sumur digunakan maupun sedang tidak digunakan (Entjang, 2000).

Jarak merupakan salah satu faktor yang dapat mempengaruhi pola penyebaran pertumbuhan dan perkembangbiakan mikroorganisme. Jarak sumur minimal 15 meter dan lebih tinggi dari sumber pencemaran sepertikakus, kandang ternak, tempat sampah, dan sebagainya (Chandra, 2006).

Penelitian ini sejalan dengan penelitian Ira, dkk (Aramana, A.T.Kawatu, Ratag, \& Umbo, 2013) yang membahas tentang lokasi sumur gali terhadap sumber-sumber pencemar seperti septic tank, kandang ternak, genangan air, tempat pembungan sampah yang harus berjarak $\geq 11$ meter dari sumur gali.Dari tabel yang telah disajikan dapat diketahui bahwa jarak sumur gali dengan septic tank yang tidak memenuhi syarat adalah $96,7 \%$ atau 29 buah sumur gali dari 30 sampel yang diperiksa. Hal ini disebabkan karena jarak jamban berada pada radius $<11$ 
meter terhadap sumur gali, hal ini tentunya bertolak belakang dengan ketentuan yang diatur yakni sebaiknya jarak dengan jamban $\geq 11$ meter. Pada jarak < 11 meter sumur gali bias terkontaminasi dengan kotoran manusia (tinja), yang mengundang bakteri pathogen yakni Escheriachia coli (E.coli), penyebab penyakit bawaan air water borne disease.

\section{Evaluasi terhadap Kondisi Sumur}

Tabel 3 memperlihatkan evaluasi potensial bahaya secara keseluruhan di Desa Sukajaya Kecamatan Lembang yang dilihat dari hasil pengukuran keadaan fisik sumur gali.

Tabel 3. Tabel Evaluasi Penilaian Resiko dan Potensi Berbahaya Keadaan Fisik dan Jarak Sumur Gali terhadap Bakteri Coliform.

\begin{tabular}{|c|c|c|c|c|}
\hline No. & $\begin{array}{c}\text { Keadaan } \\
\text { Sumur Gali }\end{array}$ & $\begin{array}{c}\text { Tidak } \\
\text { Memenuhi } \\
\text { Syarat } \\
\end{array}$ & Potensi Bahaya & Keterangan \\
\hline 1. & $\begin{array}{l}\text { Dinding } \\
\text { Sumur Gali }\end{array}$ & $100 \%$ & $\begin{array}{c}\text { Bila konstruksi dinding sumur gali tidak kedap air } \\
\text { sedalam > } 3 \text { meter maka akan mudah tercemar oleh } \\
\text { bakteri paktogen khususnya bakteri koliform karena } \\
\text { kemampuan menembus tanah secara vertical sedalam } 3 \\
\text { meter (Engjang, dalam Universitas Sumatra Utara, 2011). }\end{array}$ & $\begin{array}{l}\text { Dari hasil Pengamatan dan } \\
\text { pengukuran dilapangan } \\
\text { posisi dinding sumur gali } \\
\text { kedap air sedalam dari } 0 \\
\text { sampai } 1,5 \text { meter } \\
\end{array}$ \\
\hline 2. & $\begin{array}{c}\text { Bibir } \\
\text { Sumur Gali }\end{array}$ & $70,83 \%$ & $\begin{array}{l}\text { Menyebabkan kandungan bakteri coliform air sumur gali } \\
\text { tidak memenuhi syarat dikarenakan pengotoran dari air } \\
\text { yang mengenang disekitar permukaan lantai sumur dan } \\
\text { aspek keselamatan bagi pengguna sarana sumur gali } \\
\text { (Entjang dalam Arifin, 2009) }\end{array}$ & $\begin{array}{l}\text { Dari hasil pengamatan dan } \\
\text { pengukuran dilapangan } \\
\text { ketinggian bibir sumur } \\
\text { tertinggi } 83 \mathrm{~cm} \text { sampai } \\
\text { terendah } 6 \mathrm{~cm} \\
\end{array}$ \\
\hline 3. & $\begin{array}{c}\text { Lantai } \\
\text { Sumur Gali }\end{array}$ & $79,17 \%$ & $\begin{array}{l}\text { Lantai yang kedap air lebar kurang dari } \pm 1 \text { meter dari } \\
\text { sumur gali dapat menyebabkan air yang sudah digunakan } \\
\text { tergenang disekitar sumur gali dan merembes masuk } \\
\text { kembali kedalam sumur menyebabkan tejadi pencemaran } \\
\text { air sumur gali (Ira Y.T Aramana, dkk. 2013). }\end{array}$ & $\begin{array}{l}\text { Dari hasil pengamatan dan } \\
\text { pengukuran dilapangan } \\
\text { lebar lantai sumur gali yang } \\
\text { kedap air dari yang tidak } \\
\text { ada sampai dengan } 1 \text { meter } \\
\end{array}$ \\
\hline 4. & $\begin{array}{l}\text { Penutup } \\
\text { Sumur Gali }\end{array}$ & $54,17 \%$ & $\begin{array}{l}\text { Menyebabkan kontaminasi bakteri dari luar masuk pada } \\
\text { sumur yang tidak memakai penutup (candra, 2006) }\end{array}$ & $\begin{array}{l}\text { Dari hasi pengamatan } \\
\text { dilapangan penutup rata- } \\
\text { rata tidak memakai bahan } \\
\text { yang kedap air yang dibuat } \\
\text { dari bahan beton (semen) } \\
\text { dan ada juga yang } \\
\text { menggunakan penutup dari } \\
\text { bahan beton (semen) }\end{array}$ \\
\hline 5. & $\begin{array}{l}\text { Bakteri } \\
\text { Coliform }\end{array}$ & $100 \%$ & $\begin{array}{l}\text { Apabila air terkontaminasi bakteri coliform dapat } \\
\text { menyebabkan dampak bagi kesehatan khususnya penyakit } \\
\text { diare disentri dan types (Candra, 2006) }\end{array}$ & $\begin{array}{l}\text { Untuk saat ini air sumur } \\
\text { gali yag digunakan terlebih } \\
\text { dahulu dimasak untuk } \\
\text { keperluan air minum }\end{array}$ \\
\hline
\end{tabular}

Dari hasil pengukuran observasi yang dilakukan dapat dilihat bahwa potensi bahaya yang dapat ditimbulkan dari keadan konstruksi damana jarak sumur gali terhadap peternakan sapi akan bedamapak terkontaminasi air sumur gali oleh bakteri pathogen Coliform dan apabila dikonsumsi tampa pengakuan terlebih dahulu akan terdampak negatif bagi kesehatan. Oleh karena itu masyarakat di lingkungan Desa
Sukajaya Kecamatan Lembang Kabupaten Bandung Barat harus memanilisir potensi resiko yang terjadi baik dari kondisi fisik dan jarak maupun perlakuan sebelum dikonsumsi.

\section{Kesimpulan}

Berdasarkan hasil penelitian tentang keadaan fisik dan jarak sumur gali dengan peternakan sapi terhadap kandungan bakteri coliform air 
sumur gali di Desa Sukajaya Kecamatan Lembang Kabupaten Bandung Barat Tahun 2016. Berdasarkan dari tujuan khusus yang ingin dicapai, dapat disimpulkan sebagai berikut:

1) Sumber air yang digunakan di Desa Sukajaya Kecamatan Lembang Kabupaten Bandung Barat sebagian besar masih ada yang menggunakan sumur gali sebagai sumber air bersih yaitu sebanyak 41 kepala kelurga sementara sisanya menggunakan mata air pegunungan. Sementara sampel yang diambil sebanyak 24 sumur gali yang dipilih dari 7 RW.

2) Jarak sumur gali tidak memenuhi syarat $100 \%$ dengan jarak terdekat 1 meter dan terjauh 10, 5 meter. Sementara kandungan bakteri Coliform seluruhnya $100 \%$ tidak memenuhi syarat. Hal ini menyebabkan terjadi pencemaran sehingga ada hubungan jarak sumur gali dengan peternakan sapi terhadap Coliform.

3) Dinding sumur gali tidak memenuhi syarat $100 \%$ dimana dinding sumur tidak mencapai sedalam 3 meter dan rata-rata hanya $20-50 \mathrm{Cm}$. Sementara kandungan bakteri Coliform seluruhnya $100 \%$ tidak memenuhi syarat. Hal ini menyebabkan pencemaran sehingga ada hubungan keadaan fisik dinding sumur gali terhadap kandungan Coliform.

4) Bibir sumur gali menunjukan bahwa hasil yang memenuhi syarat berjumlah 7 sumur gali dengan presentasi $29,17 \%$ dan 17 sumur gali yang tidak memenuhi syarat dengan presentasi $70,83 \%$. Sementara kandungan bakteri Coliform seluruhnya 100 $\%$ tidak memenuhi syarat. Hal ini menyebab akan terjadi pencemaran sehingga ada hubungan keadaan fisik bibir sumur gali terhadap kandungan Coliform.
5) Lantai sumur gali menunjukan bahwa hasil yang memenuhi syarat berjumlah 5 sumur gali dengan presentasi 20,83\% dan 19 sumur gali yang tidak memenuhi syarat dengan presentasi $74,17 \%$. Sementara kandungan bakteri Coliform seluruhnya 100 $\%$ tidak memenuhi syarat. Hal ini menyebabkan terjadinya pencemaran sehingga ada hubungan keadaan fisik lantai sumur gali terhadap kandungan coliform.

6) Penutup sumur gali menunjukan bahwa hasil yang memenuhi syarat berjumlah 11 sumur gali dengan presentasi $45,83 \%$ dan 13 sumur gali yang tidak memenuhi syarat dengan presentasi 54,17 \%. Sementara kandungan bakteri Coliform seluruhnya 100 $\%$ tidak memenuhi syarat. Hali ini menyebabkan terjadi pencemaran sehingga ada hubungan keadaan fisik penutup sumur gali terhadap kandungan Coliform.

\section{Daftar Pustaka}

Aramana, I. Y., A.T.Kawatu, P., Ratag, B., \& Umbo, J. M. (2013, Agustus). Gambaran Kualitas Fisik Dan Bakteriologis Air serta Kondisi Fisik Sumur Gali Di kelurahan Bitung Karangria Kecamatan Tuminting Kota Manado. Retrieved April 06 , 2016, from http://fkm.unsrat.ac.id/wpcontent/uploads/2014/08/ira.pdf

Chandra, B. (2006). Pengantar Ilmu Kesehatan Lingkungan. Jakarta : Penerbit Buku Kedokteran .

Entjang, I. (2000). IlmuKesehatanMasyarakat. Bandung: PT. Citra Aditya Bakti.

Notoatmodjo, S. (2010). Metodologi Penelitian Kesehatan. Jakarta : Rineka Cipta. 